\title{
Digital Literacy Competence Perceptions of Classroom Teachers and Parents Regarding Themselves and Parents' Own Children
}

\author{
Mehmet Arif Ozerbas ${ }^{1}$, Feyza Nur Ocal ${ }^{2, *}$ \\ ${ }^{1}$ Faculty of Educational Science, Gazi University, Turkey \\ ${ }^{2}$ Ministry of National Education, Turkey
}

Copyright $@ 2019$ by authors, all rights reserved. Authors agree that this article remains permanently open access under the terms of the Creative Commons Attribution License 4.0 International License

\begin{abstract}
The goal of this research is to analyze digital literacy competence perceptions of classroom teachers and parents regarding themselves and parent's own children according to certain variables. Study group of this research consists of 400 classroom teachers who work in central district of Ankara province (Sincan, Etimesgut, Yenimahalle, Mamak, Keçiören), and who have accepted to fill data collection tool and 356 parents who have children in primary school. The research has been carried out in accordance with correlational survey model. As "Digital Literacy Rating Scale" has been used to determine their competence perceptions regarding the level of digital literacy of teacher and parents, SPSS 22.0 package program has been used for data analysis. The research results reveal that parents find their own levels of digital literacy as "High", but find the level of digital literacy of their children as "Medium" while the teachers find their level of digital literacy as "High". In addition to this, according to the results of the research, the seniorities of the teachers and their frequency of the Internet use have an effect on parents' perceptions on their digital literacy competence; however, this is not the case in the gender variable. The gender of parents, their educational status, and their frequency of the Internet use have affected their perceptions on their digital literacy competence. However, parents' educational status has not made a significant difference on their digital literacy competence perceptions regarding their children. Some programs that include teachers, parents and students should be organized to eliminate this difference that is seen in parents' perceptions on digital literacy competence regarding parents themselves and their children, and new researches for students should be conducted.
\end{abstract}

Keywords Literacy, New Literacy, Digital Literacy

\section{Introduction}

"Dijital okuryazarlık" is used for digital literacy. The raising importance of life long learning, the dominance of computer and the other technological devices has formed a basis for digital literacy term to become important. The consolidation of technology in our lives has brought about the fact that how, why and how much we should use and benefit from it. There are 3 different levels of Carvani, Cartelli, Fini and Ranieri (2008) which are ability to use technology. These are to build knowledge, problem solving and common knowledge. It is necessary to emphasize the co-existence of these skills which require digital competence in technological, cognitive and ethical dimensions. These 3 dimensions which underlie digital competence mean the unity of full, moral basis and digital competence in technical base. Individuals need to be at the intersection of these 3 dimensions in order to obtain a quality, safe technological life. This has led to the importance of digital literacy. Paul Gilster was the first person that shared the term "digital literacy" in 1997 but in his book "Digital Literacy", he avoided making only one definition of digital literacy. Digital literacy is not an alternative of traditional literacy but it is an extension which contribute to it and it is necessary to work, learn and socialize in modern World. (N. Churcill, Oakley \& Churchill, 2008). Martin (2008) has defined digital literacy as the individuals' improving their awareness, attitudes, and abilities, reaching digital resources, being able to evaluate of what they reach, and integrate, analyze and synthesize, create a new knowledge, communicate, reflect this process to their social lives with positive social actions in order to use digital device and he has interpreted digital literacy in three different levels. These levels have been termed: 1 . as digital competence, 2 . as digital use, and 3. as digital transformation. He has determined that the competence contains basic skills such as analysis, synthesis, 
assessment, organizing and integrating, creativity by stating that the basis of system is digital competence. He has drawn attention to professional technical competence by expressing that digital usage is central level. In digital transformation, the last step, he has emphasized that innovation and creativity are important. Digital literacy contains broader elements than Informational Technology literacy. Digital literacy reqire to ability of digital planning to solve problems experienced by using knowledge, atttude and personal qualities. Digital literate should reflect current developments to their digital literacy by being aware of themselves.

Soylu and Akkoyunlu (2010) have made definition as "it includes reading and writing of numerical texts in addition to reaching knowledge, editing knowledge, analysing, interpreting, transmitting, and the process of producing a knowledge by using numerical technologies." Apart from all these definitions, there are ones has defined digital literacy as photographic skills, production skills and ability to acquire knowledge.( Özbay and Özdemir conveyed from Alkalai and Hamburger,2014) The authors have taken into consideration the requirements of their era and of their own community while defining digital literacy. It is important to observe changes in our lives as individuals of digital era. To be able to detect dimensions of cultural change that we do not know its end, but we have an idea about the beginning, it seems as prior condition for us to be able to lead a quality life. In contrast to former technologies, improvement of faster web based technology, gaining importance of software companies, being used of cheap and productive software include companies in this digital pool. The effects on social life of digital literacy, which is now known to have a wide impact on the economic and political context, is now undeniable. In the study on teacher candidates by Yanık (2010), it is concluded that there is a significant difference among the levels of basic skills of computer literacy, programming and computer awareness according to their departments, however there is no significant difference among them in terms of using software skills. It is concluded that according to their departments, there is a significant difference among teachers in terms of the use of the Internet in research and its sub-factors of delightfulness for using on education; however, there is no significant difference among them in terms of the use of the Internet on education, social interaction, communication, and knowledge sharing.

According to their frequency of computer use of teacher candidates, the mean of those who never use the computer in a week and the mean point of those who use 1-10, 11-20 and 21- + hours have differed in terms of their basic skills, basic software skills, programming and computer awareness. It is concluded that especially, the perceptions of basic skills and applying to software skills of the teacher candidates using 21- + hour computers in a week are much more than others. In that case, the factor of using the Internet intensively has revealed the fact that teachers are motivated to use computers. In their research, Yıldız, Kahyaoğlu and Kaya (2012) have assessed the numerical literacy levels of secondary school students studying in the province of Siirt in terms of variables such as their gender, high schools and classroom levels; they have concluded that the levels of their numerical literacy are above average. When numerical literacy and its sub dimensions of secondary school students are analyzed according to variables of their high school types; numerical literacy and technology literacy with sub dimensions, computer literacy and media literacy levels of the students studying in Anatolian high school are higher than levels of students studying in Science high school. The differences between high school groups in this research can only be eliminated if the technological education given in schools takes part in education programs. Since digital literacy is the ability to understand new promises and new opportunities that arise with digital technologies. It ensures the safe participation to technology for youth. It helps provide information about the technology use and increases learning as well as being an add-on to the teaching. Youth can create and share their own new media, cartoons, movies and music. The researches have revealed that the use of technology by the youth within and outside the school has changed and increased in the last 20 years.

The teachers who will give this digital competence to students need to have this competence first. It is unlikely that children who are left in a sea without a limit can take control of this digital stack and maintain a useful use, and the ability of their parents who are always with them to isolate themselves from this world or to find their right way on this digital world, shaping the teachers themselves to life, to having enough power to respond to the needs of children; their knowledge about their digital literacy, digital literacy levels, and digital literacy views are a significant problem. The teachers, students and parents' opinions regarding digital literacy in these problems mentioned are discussed in accordance with certain variables in the scope of this research.

\section{The Goal of This Research}

The goal of this research is to analyze classroom teachers and parents' perceptions of digital literacy competence regarding themselves and parents' own children according to certain variables.

The following questions will be sought in the framework of this general purpose.

1. Do the digital literacy assessments of the classroom teachers regarding themselves differ according to their;
a. gender
b. seniority
c. the frequency of their Internet use?

2. Do the digital literacy assessments of the parents regarding themselves change significantly according to their; 

a. gender
b. educational status
c. the frequency of their Internet use?

3. Do the digital literacy assessments of the parents regarding their children differ according to their;
a. gender
b. educational status
c. the frequency of their Internet use?

\section{Method}

\subsection{Research Model}

This study, which analyzes the digital literacy competence perceptions of classroom teachers and parents regarding themselves, and parents' children has been conducted in correlational survey model.

\subsection{Study Group}

The study group of the research consists of classroom teachers who voluntarily have accepted to fill data collection tool in the first term of the 2016-2017 school year and parents who have children in primary school.

\subsection{Data Collection Tool}

"Digital Literacy Rating Scale” which is developed by Acar and Şimşek (2015) has been used. Cronbach $\alpha$ value of the scale has been found as .980 . This value reveals that the scale is highly reliable.

\subsection{The Analyzing of Data}

The data obtained by the scale in the research has been transferred to computer to be analyzed by using SPSS 22.0 package program. In the analysis of the data, the following steps have been done respectively. Demographic features of the teachers and parents in the research have been indicated by using frequency (f) and percentage (\%).Unrelated sample t-test has been used to determine whether assessments of their digital literacy regarding teachers themselves, parents themselves and parents' own children have a significant difference according to gender of participants as related sample t-test has been used to determine whether there is a significant difference between assessments of their digital literacy regarding, parents themselves and their own children. One way ANOVA has been used to determine whether assessments of their digital literacy regarding teachers themselves, parents themselves and parents' own children have a significant difference according to educational status, the frequency of the Internet use and seniorities of participants. When the results of ANOVA is meaningful if variences are equal Scheffe test has been used if not Dunnett's C is used.
Significance level was accepted as $\mathrm{p}=.05$ in all analysis.

\section{Findings}

\subsection{Digital Literacy Assessments of Primary School Teachers}

The findings obtained regarding classroom teachers' digital literacy levels which are the first sub-problem of the research are given in Table 1.

Table 1. The Levels of Digital Literacy of Classroom Teachers

\begin{tabular}{lllllll}
\hline & N & Min & Max & X & SS & Level \\
\hline Teacher & 400 & 48 & 200 & 149,58 & 30,79 & High \\
\hline
\end{tabular}

When the whole scale is taken into consideration, the classroom teachers' total score $(X=149,58)$ which is obtained from digital literacy scale corresponds to score interval which is "High". It means that, the classroom teachers feel themselves more competent in terms of digital literacy.

\subsubsection{Determination of Digital Literacy Perceptions of Classroom Teachers According to Gender Variable}

T-test is used to determine whether assessments of their digital literacy regarding classroom teachers themselves have a significant difference according to gender of participants, and the data is shown in Table 2.

Table 2. Digital Literacy Levels of Teachers by Gender Variables

\begin{tabular}{ccccccc}
\hline Gender & $\mathrm{N}$ & $\mathrm{X}$ & $\mathrm{S}$ & $\mathrm{sd}$ & $\mathrm{t}$ & $\mathrm{P}$ \\
\hline Female & 306 & 149,91 & 30.77 & 398 & .241 & .927 \\
\hline Male & 94 & 149,57 & 33.09 & & &
\end{tabular}

Digital literacy competence perceptions of classroom teachers do not differ significantly according to their gender [ $\mathrm{t}(398)=.241, \mathrm{p}>.05$ ]. It is clear that gender is not an effective variable when the mean scores of female teachers' digital literacy scale $(X=149,91)$ are compared to the mean scores of male teachers' digital literacy scale $(\mathrm{X}=149,57)$.

\subsubsection{Determination of Digital Literacy Competence Perceptions of Classroom Teachers according to Their Seniority Variable}

As it can be seen in the Table 3 which contains descriptive statistics, the number of teacher with 17-25 years seniority is more than the teachers in the other seniority groups $(\mathrm{N}=167)$. When it is looked at the arithmetic mean scores of teachers' digital literacy, arithmetic mean scores of digital literacy of teachers with $0-5$ years seniority are more than arithmetic mean scores of other teachers $(\mathrm{X}=171,24)$. One way ANOVA is used to understand whether classroom teachers' digital literacy competence perceptions have a significant difference according to their seniority, and it is shown in the Table 4. 
Table 3. Digital Literacy Levels of Teachers by Seniority Variables Descriptive Statistics

\begin{tabular}{llll}
\hline SENIORITY & $\mathrm{N}$ & $\mathrm{X}$ & Std. Deviation \\
\hline 0 -5 years & 29 & 171,2414 & 20,37445 \\
\hline $6-10$ years & 55 & 161,0545 & 26,22581 \\
\hline $11-16$ years & 88 & 159,3977 & 25,48452 \\
\hline $17-25$ years & 164 & 145,2195 & 31,10995 \\
\hline 26 years + & 64 & 127,5938 & 28,72791 \\
\hline Total & 400 & 149,5825 & 30,79576 \\
\hline
\end{tabular}

Table 4. Digital Literacy Levels of Teachers by Seniority Variable

\begin{tabular}{lllllll}
\hline $\begin{array}{l}\text { Source of } \\
\text { variance }\end{array}$ & Sum of squares & sd & Mean of squares & F & p & Significant Difference \\
\hline Among Groups & 63386,516 & 4 & 15846,629 & 19,870 &, 000 & $1-4,1-5,2-4,2-5,3-4,3-5$ \\
\hline Within Groups & 315016,761 & 395 & 797,511 & & & \\
\hline Total & 378403,278 & 399 & & & \\
\hline
\end{tabular}

Classroom teachers' perceptions of their digital literacy competence differ significantly according to their seniority [F $(4,395)=.962, \mathrm{p}<.05]$. According to the results of the post-hoc Scheffe test conducted to find out among which groups have differences which are among seniority groups, there is a significant difference between teachers with 0-5 years seniority and teachers with 17-25 years and over 26 years seniority, between teachers with 6-10 years seniority and teachers with 17-25 and over 26 years seniority, between teachers with 11-16 years seniority and teachers 17-25 and over 26 years seniority. When the mean score differences are examined, it is seen that as the seniority of the teachers increase, the decreasing in their assessments in terms of digital literacy levels are observed.

\subsubsection{Determination of Classroom Teachers' Perceptions of Digital Literacy Competence According to the Variable of Digital Vehicle Use Frequency}

As it is seen in the table, participants stating that they use the Internet in their daily life, but not very often are more than the other participants ( $\mathrm{N}=227)$. The group that has the highest arithmetic mean score of digital literacy scale is comprised of teachers stating that I can't do without using the internet in their assessments about their digital literacy $(\mathrm{X}=166,51)$. One Way Anova Test is used to understand whether digital literacy competence perceptions of teacher teachers differ significantly according to their frequency of internet use and it is shown in table 6 .

Digital literacy competence perceptions of classroom teachers differ significantly according to their frequency of the Internet use $[\mathrm{F}(4,395)=17.511, \mathrm{p}<.05]$. According to the results of the post-hoc Scheffe test conducted to find out among which groups there is a significant difference between the ones stating that they never use the Internet and the other groups. There is a significant difference between the users stating that they use the Internet in their daily lives but not very often and users stating that they use the Internet only when it is necessary. There is a significant difference between the teachers stating that they use the Internet very often except from their job and teachers stating that they use the Internet only when it is necessary and who state that they use the Internet in their daily lives but not very often and also between the teachers stating that I can't do without using the Internet and the teachers using the Internet in their daily lives but not very often. When we take consideration into the mean arithmetic score of digital literacy scale of classroom teachers, it can be interpreted that the more frequency of the Internet use increases, the more their assessments about their digital literacy increase. 
Table 5. Teachers' Digital Literacy Level-Frequency-Descriptive Statistics

\begin{tabular}{lccc}
\hline Frequency & $\mathrm{N}$ & Mean & Std. Deviation \\
\hline I never use the Internet. & 5 & 165,0000 & 42,00000 \\
\hline I use the Internet only when it is necessary. & 48 & 125,9583 & 28,94085 \\
\hline I use the Internet in my daily life, but not very often. & 227 & 146,4097 & 30,18885 \\
\hline I use the internet very often except from my job. & 68 & 162,7647 & 23,80713 \\
\hline I can't do without using the internet. & 52 & 166,5192 & 24,67156 \\
\hline Total & 400 & 149,5825 & 30,79576 \\
\hline
\end{tabular}

Table 6. Digital Literacy Level of Teachers-Frequency of Internet Use

\begin{tabular}{lllllll}
\hline Source of variance & Sum of squares & sd & Mean of Squares & F & P & Significant Difference \\
\hline Among Groups & 56995,246 & 4 & 14248,812 & 17,511 &, 000 & $3-2,4-2,4-3,5-2,5-3$ \\
\hline Wihin Groups & 321408,031 & 395 & 813,691 & & & \\
\hline Total & 378403,278 & 399 & & & & \\
\hline
\end{tabular}

\subsection{Findings of the Parents about the Second Sub-Problem of the Research}

In the second sub-problem of the study, there are findings about the parents' digital literacy levels.

Table 7. Digital Literacy Levels of Parents themselves

\begin{tabular}{lllllll}
\hline & N & Min & Max & X & SS & Level \\
\hline Parent & 396 & 41 & 200 & 148,18 & 41,941 & High \\
\hline
\end{tabular}

When it is taken into consideration the whole scale, parents' arithmetic mean scores $(X=148,18)$ that are obtained from digital literacy scale by parents correspond to score interval that is "High". It means that the parents feel themselves as "High" in terms of their digital literacy.

\subsubsection{Is There a Significant Difference Between the}

Gender Variables and the Literacy Views of Parents?

Table 8. Literacy Views of Parents by Gender Variable

\begin{tabular}{lllllll}
\hline Gender & $\mathbf{N}$ & $\mathbf{X}$ & $\mathbf{S}$ & sd & T & p \\
\hline Female & 218 & 143,65 & 42,60 & 398 & $-2,717$ &, 007 \\
\hline Male & 138 & 156,07 & 41,07 & & & \\
\hline
\end{tabular}

Digital literacy competence perceptions of parents regarding themselves differ significantly according to their gender [t (398) $=-2,717, \mathrm{p}<.05]$. When the arithmetic mean scores of digital literacy scale of female parents $(X=143,65)$ are compared to male parents' $(X=143,65)$, their own digital literacy assessments of male parents are higher. It can be concluded that male parents feel more competent in terms of digital literacy than female parents.

4.2.2. Results of Digital Literacy Competence Perceptions of Parents Regarding Themselves according to Variable of Educational Status

As it is seen in Table 9, the most of parents in the table are high school graduated. $(\mathrm{N}=159)$. When the arithmetic mean scores of parents' digital literacy scale are compared, it is seen that parents who have received education of postgraduate have higher mean. $(X=174,33)$. In this context, it is concluded that parents who have received education of postgraduate feel themselves more competent in terms of their digital literacy.

Table 9. Statistics of Parents' Educational Status

\begin{tabular}{lccc}
\hline Educational Status & $\mathbf{N}$ & $\mathbf{X}$ & SS \\
\hline Primary school & 68 & 118,0294 & 42,68593 \\
\hline Secondary school & 46 & 128,9130 & 41,09708 \\
\hline High School & 159 & 157,5723 & 38,54169 \\
\hline Associate Degree & 15 & 163,6667 & 41,20448 \\
\hline Undergraduate & 62 & 166,8226 & 30,53755 \\
\hline Postgraduate & 6 & 174,3333 & 22,47369 \\
\hline Total & 356 & 148,4663 & 42,39667 \\
\hline
\end{tabular}

As it is seen in the table 10 , there is a significant difference between digital literacy perceptions of parents regarding themselves and their educational status $[F(5,350)=16,570, p<05]$. According to the results of the post-hoc Scheffe test conducted to find out among which groups there is a significant difference between parents who are high school graduated and parents who are graduated from primary and secondary schools. There is a significant difference between parents with associate degree and parents who are graduated from primary school. There is a significant difference between parents who are graduated from high school and parents who are graduated from primary and secondary school. There is also a significant difference between parents who have received postgraduate education and parents who are graduated from primary school. 
Table 10. Parents' Learning Status ANOVA Results

\begin{tabular}{lllllll}
\hline Source of Variance & Sum of Squares & sd & Mean of Squares & F & P & Significant difference \\
\hline Among Groups & 122138,369 & 5 & 24427,674 & 16,570 &, 000 & $3-1,3-2,4-1,5-1,5-2,6-1$ \\
\hline Within Groups & 515966,227 & 350 & 1474,189 & & & \\
\hline Total & 638104,596 & 355 & & & & \\
\hline
\end{tabular}

\subsubsection{Parents' Frequency of Using Internet}

Descriptive statistics and other statistics, that are another variable of frequency of the Internet use in analyze of parent's digital literacy regarding themselves are explained in tables.

Table 11. The Frequency of Internet Use of Parents Descriptive Statistics

\begin{tabular}{lccc}
\hline Frequency & N & Mean & Std. Deviation \\
\hline I never use the Internet. & 27 & 89,2222 & 40,97122 \\
\hline I use the Internet only when it is necessary. & 102 & 131,4412 & 43,09799 \\
\hline I use the Internet in my daily life but not very often. & 191 & 160,6649 & 32,82269 \\
\hline I use the Internet very often except from my job. & 25 & 177,6000 & 23,65023 \\
\hline I can't do without using the Internet. & 11 & 173,7273 & 27,83915 \\
\hline Total & 356 & 148,4663 & 42,39667 \\
\hline
\end{tabular}

As it is seen in the table 11, participants stating that they use the Internet in their daily lives, but not very often are more than the other participants $(\mathrm{N}=191)$. The group having the highest arithmetic mean score about their own digital literacy is the group stating that they use the Internet very often except from their jobs. $(X=177,60)$. One Way Anova Test is used to understand whether digital literacy competence perceptions of parents differ significantly according to their frequency of the Internet use and it is shown in table 12.

Table 12. Parent - Internet Usage Frequency ANOVA Results

\begin{tabular}{lllllll}
\hline Source of Variance & Sum of Squares & sd & Mean of Squares & F & p & Significant Difference \\
\hline Among Groups & 180992,045 & 4 & 45248,011 & 34,744 &, 000 & $\begin{array}{l}2-1,3-1,3-2,4-1,4-2,5-1, \\
5-2\end{array}$ \\
\hline Within Groups & 457112,551 & 351 & 1302,315 & & & \\
\hline Total & 638104,596 & 355 & & & \\
\hline
\end{tabular}

Digital literacy competence perceptions of parents of their own differ significantly according to their frequency of Internet use $[\mathrm{F}(4,351)=34,744, \mathrm{p}<.05]$. According to the results of the post-hoc Scheffe test conducted to find out among which groups there is a significant difference between participants stating that they use the Internet when it is necessary and participants who never use the Internet. There is a significant difference among participants who use the Internet in their daily lives but not very often and participants who never use the Internet and the ones using the Internet only when it is necessary. There is also a significant difference among participants using the Internet very often except from their jobs and the participants who never use the Internet and the ones using the Internet only when it is necessary. There is a significant difference among participants stating that they can't do without using the Internet and participants who never use the Internet and the ones using the Internet only when it is necessary. When we take into consideration the differences among means, it can be concluded that the more frequency of Internet use increases, the more their assessments of their own digital literacy increase. 


\subsection{Digital Literacy Assessments for Parents of Children}

The findings of the digital literacy level of parents' children, who are the third sub-problem of the research, are given in Table 13.

Table 13. Digital Literacy Levels of Parents' Children

\begin{tabular}{lllllll}
\hline & N & Min & Max & X & SS & Level \\
\hline Student & 356 & 41 & 200 & 108.41 & 41,361 & Medium \\
\hline
\end{tabular}

When the whole scale is taking into consideration, the students' total score $(X=108,41)$ from digital literacy scale corresponds to score interval which is "Medium". It means that parents think their own children as 'Medium' in terms of their digital literacy.

\subsubsection{Digital Literacy Levels of Parents of Children by Gender Variable}

In order to determine whether literacy levels of parents regarding their children have differed significantly according to their gender, t-test is conducted and the data are shown in Table 14.

Table 14. Opinions of Parents of Children by Gender Variable

\begin{tabular}{lllllll}
\hline Gender & $\mathbf{N}$ & $\mathbf{X}$ & $\mathbf{S}$ & $\mathbf{s d}$ & $\mathbf{t}$ & $\mathbf{p}$ \\
\hline Female & 217 & 112,38 & 41,21 & 353 & 2,176 & .030 \\
\hline Male & 138 & 102,65 & 40,79 & & & \\
\hline
\end{tabular}

The digital literacy competence perceptions of parents regarding their children have differed significantly according to their own gender [t $(353)=2,176 ; \mathrm{p}<.05]$. When the digital literacy mean score of female parents regarding their children $(X=112,38)$ is compared to the digital literacy mean score of male parents regarding their children $(X=102,65)$, it is concluded that the digital literacy assessments of female parents regarding their children are higher.

\subsubsection{Parents' Evaluations on the Children -Familiarity with Their State}

Table 15. Assessments of Parents Regarding Children -Educational Status-Descriptive Statistics

\begin{tabular}{cccc}
\hline Educational Status & N & X & SS \\
\hline Primary School & 68 & 100,3529 & 36,78731 \\
\hline Secondary School & 45 & 114,7333 & 41,02848 \\
\hline High School & 159 & 111,9182 & 43,57664 \\
\hline Associate Degree & 15 & 75,2667 & 25,57193 \\
\hline Undergraduate & 62 & 109,6935 & 38,09677 \\
\hline Postgraduate & 6 & 140,5000 & 43,66578 \\
\hline Total & 355 & 108,6056 & 41,26889 \\
\hline
\end{tabular}

As it can be understood from the table, the mean scores of the digital literacy scale of children who have parents who have received postgraduate education are higher than the other groups. ( $X=140,50)$. The parents who have received postgraduate education believe that their children are more competent in terms of digital literacy.

As it is seen in table 16, there is a significant difference between digital literacy competence perceptions of parents regarding their children and their educational status. ( $\mathrm{F}$ $(5,349)=3,773 ; \mathrm{p}<05)$. According to the results of the post-hoc Scheffe test conducted to find out among which groups there is a significant difference between parents who are graduated from secondary school, high school, associate degree and postgraduate differ significantly from parents who have received undergraduate education.

Table 16. Assessment of Parents Regarding Children - Educational Status - ANOVA Results

\begin{tabular}{lcccccc}
\hline Source of Variance & Sum of Squares & sd & Mean of Squares & F & P & Significant Difference \\
\hline Among Groups & 30914,911 & 5 & 6182,982 & 3,773 &, 002 & $2-4,3-4,5-4,6-4$ \\
\hline Within Groups & 571989,877 & 349 & 1638,939 & & & \\
\hline Total & 602904,789 & 354 & & & & \\
\hline
\end{tabular}

4.3.3. The Views of Parents on the Use of Internet Literacy

Table 17. Assessments of Parents Regarding Their Children - Frequency - Descriptive Statistics

\begin{tabular}{lccc}
\hline Frequency & N & Mean & Std. Deviation \\
\hline I never use the Internet & 27 & 85,2963 & 32,36786 \\
\hline I use the Internet only when it is necessary. & 101 & 111,9901 & 41,99226 \\
\hline I use the Internet in my daily life but not very often. & 192 & 109,6354 & 41,63130 \\
\hline I use the Internet very often except from my job. & 25 & 111,3600 & 37,48653 \\
\hline I can't do without using the Internet. & 11 & 104,4545 & 47,53602 \\
\hline Total & 356 & 108,4185 & 41,36164 \\
\hline
\end{tabular}


Table 18. Parents' Opinions on Children -Spellence- ANOVA Results

\begin{tabular}{lcccccc}
\hline Source of Variance & Sum of Squares & sd & Mean of Squares & F & p & Significant Difference \\
\hline Among Groups & 16397,051 & 4 & 4099,263 & 2,435 &, 047 & $2-1,3-1$ \\
\hline Within Groups & 590931,586 & 351 & 1683,566 & & \\
\hline Total & 607328,638 & & & & \\
\hline
\end{tabular}

When digital literacy competence perceptions of parents regarding their children are evaluated, the group that has the highest arithmetic mean is the group stating that they use the Internet very often except from their jobs $(X=111,99)$. One way ANOVA was used to determine whether digital literacy competence perceptions of parents regarding their children have a significant difference according to their frequency of the Internet use and it is shown in table 18

Digital literacy competence perceptions of parents regarding themselves differ significantly according to their frequency of Internet use $(\mathrm{F}(4,351)=2,435, \mathrm{p}<.05)$. According to the results of the post-hoc Scheffe test conducted to find out among which groups there is a significant difference between participants stating that they use the Internet only when it is necessary and participants stating that they use the Internet in their daily life but not very often and the ones stating that they never use the Internet.

\section{Conclusions and Debate}

\subsection{Results Regarding Digital Literacy Competence Perceptions of Classroom Teachers}

Classroom teachers feel themselves as "High" in terms of the level of digital literacy. Gender is not a distinctive variable for classroom teachers in terms of their perceptions of digital literacy. In their study on self-efficacy perceptions regarding computer, Seferoğlu and Akbiyık (2005) found similar results by stating that there is no significant difference between female and male teachers in terms of computer self-efficacy perception. In their researches that analyzing teacher candidates of numerical competence levels, Kazu and Erten (2014) while finding a significant difference in the sub-dimensions of the scale according to gender variable, they have reached similar results by getting no significant differences in the general numerical competence dimension. The age of classroom teachers is an effective variable on digital literacy competence perceptions of teachers. Teachers aged 21-25 feel more competent in terms of the level of digital literacy. Akkoyunlu and Soylu have analyzed the numerical competence of teachers in 4 subheadings as awareness, motivation, technical access and they've found similar results by finding numerical competence mean scores of teachers aged 20-24 as higher than the others.
It is seen that the more seniorities of the teachers increase, the more mean scores of the digital literacy scale decrease. The teachers who are new in terms of working time feel themselves more competent regarding digital literacy. In his research that Baş( 2011) have analyzed self-efficacy beliefs of educational internet use of primary school teachers in terms of different variables and have found similar results by finding self-efficacy beliefs of educational internet use of teachers much higher than other teachers. The frequency of Internet use is an effective variable on digital literacy competence perceptions of teachers. Except from the ones who never use the Internet in their daily lives mean scores that teachers have taken from the scale have advanced linearly and the more the frequency of Internet use increase, the more they feel competent.

\subsection{Results of Parents' Perceptions of Their Own Digital Literacy Competence}

Parents feel themselves as 'High' in terms of digital literacy. Gender is an effective variable on digital literacy competence perception of parents regarding themselves. Fathers feel more competent than mothers in terms of digital literacy. In his research that Dinçer (2012) have analyzed the effect of the relationship between student and parents on their computer literacies, he has found the fathers' level of computer literacy as higher than mothers. In their researches named the Internet habit of children and secure Internet use, Kaşıç̧ı, Çağıltay, Karakuş, Kurşun and Ogen (2014) have determined that \%28,6 of Turkish parents and \%83 of European parents who participated the research use the Internet and among Turkish parents $49 \%$ of males and $23,5 \%$ of females use the Internet. They have concluded that there is no difference similar to this between genders of parents in European. Educational status is an effective variable on the digital literacy competence perceptions of parents regarding themselves. As educational level increases, it is seen that mean scores that are obtained from scale increase. In this case, parents who have higher level of educational status feel themselves more competent in this context.

\subsection{Results of Digital Literacy Competence Perceptions of Parents Regarding Their Children}

Parents think their children as 'Medium' in terms of their digital literacy competence perceptions. Gender is an effective variable on the digital literacy competence 
perceptions of parents regarding their children. It is found that the digital literacy assessments of female parents regarding their children are higher. Educational status is an effective variable on the digital literacy competent perceptions of parents regarding their children. It is found that digital literacy assessment points of parents who studied associate degree regarding their children are higher. In their research that they have analyzed the friendship loyalty and Internet addiction of adolescents according to the educational levels of parents, Çevik and Çelikkaleli (2010) have determined that children whose parents studied in university use much more Internet and they have found similar results. In the research that Yildiz and Seferoğlu (2014) analyzed their ideas about the digital divide levels of primary school students in terms of different variables, they again have found similar results by determining that the more educational level of mother increases, the more the level of information and communication technologies literacy increases.

\section{REFERENCES}

[1] Acar, Ç. (2015). Anne ve babaların ilkokul ortaokul lise öğrencisi çocukları ile kendilerinin dijital okuryazarlıkların a ilişkin görüşleri. (masters' thesis) Retrieved from https://tez.yok.gov.tr

[2] Akkoyunlu, B., \& Soylu, M. Y. (2010). Öğretmenlerin sayısal yetkinlikleri üzerine bir çalışma. Türk Kütüphaneci liği, 24(4), 748-768. Retrieved fromhttp://www.tk.org.tr/in dex.php/TK/ article/viewFile/449/439

[3] Aydın, A. (2015). Dijital vatandaşlık. Türk Kütüphaneciliği, 29(1), 142-146. Retrieved from http://www. tk.org.tr/index .php/ TK/article/view/2530

[4] Bahar, H. H., \& Uludağ, E., \& Kaplan K. (2009). İlköğretim öğretmenlerinin bilgisayar ve internet tutumlarının incelenmesi. Erzincan Eğitim Fakültesi Dergisi, 11(2), 67-83. Retrieved from https://www.pegem.net/dosyalar/do kuman/131133-20120405162729-67-83.pdf

[5] Baş, G. (2011). İlköğretim öğretmenlerinin eğitsel internet kullanımı öz-yeterlik inanç larının farklı değişkenler açısından incelenmesi. Eğitim Teknolojisi Kuram ve Uygulama, 1(2), 35-51. Retrieved from http://dergipark.ula kbim.gov.tr/etku/article/view/ 5000055474

[6] Calvani, A., \& Fini, A., \& Ranieri, M. (2009). Models and instruments for assessing digital competence at school. Tecnologie Didattiche, 48, 39-46. Retrieved from http://docplayer.it/8696490-Valutare-la-modelli-teorici-e-c ompetenza-digitale-strumenti-applicativi-assessing-digitalcompetence-theoretical-models-and-tools.html.

[7] Churchill, N., \& Ping, L.Ç., \& Oakley, G., \& Churchill, D. (2008). Digital storytelling and digital literacy learning. International Conference on Information Communication Technologies in Education, Island. Retrieved from https://www.academia.edu/2818859/Digital_storytelling_a nd_digital_literacy_learning.
[8] Çevik, G., B., \& Çelikkaleli, Ö. (2010). Ergenlerin arkadaş bağlılığı ve internet bağımlığının cinsiyet ebeveyn tutumu ve anne-baba eğitim düzeylerine göre incelenmesi. Ç.Ü. Sosyal Bilimler Enstitüsü Dergisi, 19(3), 225-240. Retrieved from http://dergipark.ulakbim.gov.tr/ cusosbil/ar ticle/view/5000001458

[9] Çubuk, M. (2010). Prof. Dr. John Hartley: Dijital okur-yazarlık olmadan, hayal gücümüzü modernize edemiyoruz. Bilişim Kültürü Dergisi, 38, 30-35. Retrieved from http://www.bilisimdergisi. org/s126/pdf/30-35.pdf

[10] Çubukçu, A. (2013). Türkiye'de dijital vatandaşlık algısı ve bu algıyı internetin bilinçli, güvenli ve etkin kullanımı ile artırma yöntemleri. Middle Eastern \& African Journal of Educational Research 5, 148-174. Retrieved from http://docplayer.biz.tr/1519740-Turkiye-de-dijital-vatandas lik-algisi-ve-bu-algiyi-internetin-bilincli-guvenli-ve-etkinkullanimi-ile-artirma-yontemleri.html

[11] Eshet, Y. (2004). Digital Literacy: A Conceptual framework for survival skills in the digital era. Jl. of Educational Multimedia and Hypermedi, 13(1), 93-106. Retrieved from http://www.openu.ac.il/personal_sites/download/Digital-lit eracy2004-JEMH.pdf.

[12] Hague, C., \& Payton, S. (2010). Digital literacy across the curriculum. Bristol, Retrieved from http://www.nfer.ac.uk/ publications/FUTL06/FUTL06.pdf.

[13] İşçioğlu, E. \& Kocakuşak, S. (2012). İlköğretim sınıf öğretmeni adaylarının sayısal okuryazarlık düzeyleri ve teknoloji algıları. Hacettepe Üniversitesi Eğitim Fakültesi Dergisi 2, 15-24. Retrieved from http://www.efdergi.hacett epe.edu.tr/yonetim/icerik/makaleler/630-published.pdf

[14] Kalayc1, C. (2013). Dijital bölünme, dijital yoksulluk ve uluslararası ticaret. Atatürk Üniversitesi İktisadi ve İdari Bilimler Dergisi, 27(3), 145-162. Retrieved from http://e-d ergi.atauni.edu.tr/atauniiibd/article/view/1025008954

[15] Karasar, N. (2014). Bilimsel araştırma yöntemleri. Ankara: Nobel.

[16] Kaşıkçı, D. N., \& Çağıltay, K., \& Karakuş, T., \& Kurşun, E., \& Ogan, C. (2014). Türkiye ve Avrupa'daki çocukların internet alışkanlıkları ve güvenli internet kullanımı. Eğitim ve Bilim Dergisi, 39(171), 230-243. Retrieved from http://egitimvebilim.t ed.org.tr/index.php/EB/article/view/1 867

[17] Kazu, İ. E., \& Erten, P. (2014). Öğretmen adaylarının sayısal yetkinlik düzeyleri. Bartın Üniversitesi Eğitim Fakültesi Dergisi, 3(2), 132 - 152. Retrieved from http://buefad.barti n.edu.tr/ article/viewFile/1082000121/1082000107

[18] Martin, A. (2008).Digital Literacy and the "Digital Society". Lankshare, C. \& Knobel, M. (Eds.). (2008). Digital Literacies (pp.151-176). New York: Peter Lang Publishing.

[19] Ribble, M. (2009) Raising a Digital Child. 1st Internationa Society for Technology in Education. Retrieved from http://www.iste.org/docs /excerpts/DICIPA-excerpt.pdf.

[20] Seferoğlu, S. S., \& Akbiyık, C. (2015). İlköğretim öğretmenlerinin bilgisayara yönelik öz-yeterlik algıları üzerine bir çalışma. Eğitim Araştırmaları-Eurasian Journal of Educational Research, 19, 89-101. Retrieved from http://yunus.hun.edu.tr/ sadi/yayin/Seferoglu-Akbiyik_EJ ER-2005_Ogretmen-OzYeterlik.pdf 
[21] Yanık, C. (2010). Öğretmen adaylarının bilgisayar okuryazarlık algıları ile internet kullanımına yönelik tutumları arasındaki ilișki. Hacettepe Üniversitesi Eğitim Fakültesi Dergisi (H. U. Journal of Education), 39, 371-382. Retrieved from http://www.efdergi.hacettepe.edu.tr/ yonetim/icerik/makaleler/485-published.pdf

[22] Yıldız, Ç., \& Kahyaoğşu, M., \& Kaya, M. F. (2012). Siirt ilindeki ortaöğretim öğrencileri nin sayısal okuryazarlık düzeylerinin cinsiyet, sınıf ve öğrenim gördüğü lise türüne göre farklılaşmasının incelenmesi. Uşak Üniversitesi Sosyal Bilimler Dergisi, 5(3). Retrieved from http://dergip ark.ulakbim.gov.tr/usaksosbil/article/view/5000035860/50 00034782 . 